\title{
Entrepreneurship in Agriculture: An Innovative Initiative
}

\author{
Dr. Deepa Kumari, Assistant Professor, SBS, Sharda University \\ Ms. Deepa Chauhan, Assistant Professor, SBS, Sharda University
}

\begin{abstract}
Sustainable growth in agriculture sector is an important issue for all the countries. This Paper is an attempt to analyse the significance of agriculture entrepreneurship and government initiatives to strengthen the entrepreneurship spirit. . India had always been an agrarian economy. While from a rote agrarian economy, India is now a witness to growing allied agrarian activities such as foodprocessing, floriculture, fisheries and many more, there are many basic problems that have been ailing the agrarian ecosystem. The spectrum of problem has only increased with the passage of time that include poor farm output due to a variety of reasons, shrinking land, outdated infrastructure and access to credit for the agrarian community. India has a huge potential to one of the leading agriculture-based economies, if these problems are corrected on time. This paper discusses the role and importance of entrepreneurship in solving the problem of mankind's oldest profession. This paper takes up cases of three agriprenuerial companies and discusses their forte, intervention and scope for such ventures. The paper also highlights the role of the Indian government in the boosting the necessary steps for agribusiness and its' growth.
\end{abstract}

Keywords: Entrepreneurship, Start-up, Government, Skill development, economy

\section{Introduction}

India is an agricultural country, and agriculture is the foundation of our country's economy. In our country, agriculture is not just farming; it is an art of living. The entire country depends on agriculture. The hunger of the people is eradicated only through agriculture. This is the backbone of our country's governance.India is primarily an agricultural country. Agriculture is the most important occupation for most Indian families. Agriculture accounts for about 16\% (16\%) of total GDP in India and 10\% (10\%) of total exports.It has become the largest country in more than $60 \%$ of the land area of India in terms of total arable land. Agricultural products of significant economic value include rice, wheat, potatoes, tomatoes, onions, mangoes, sugar-cane, beans, cotton, etc. Food is essential for life. We depend on agricultural production for our food needs. Cereals like millet, cereals, pulses etc. are produced on a large scale in India. A large proportion of food manufactured within the country is consumed. 
In addition to agriculture with an occupational bias, subsistence farming is widespread, with an emphasis on farming production for farming. Traditionally, agriculture is considered the easiest way to obtain food for the family. Agriculture is the more 'way of life' in India, then 'business conditions'.

Exports: India has exported additional food and agricultural products. A large part of India's export trade is based on agricultural products, such as jute, tea, tobacco, coffee, spices and sugar. It helps to increase foreign exchange.

Agro-based industries can thrive in rural areas where labor is abundant and labor costs are low. SMEs are set up to supplement the traditional agricultural income on a large scale at the village level and create alternative sources of income.Today; India is emerging as a major startup destination with new entrepreneurial spirit. Unfortunately, the agricultural sector has remained untouched .The government has taken an initiative to provide financial incentives to farmers-cumentrepreneurs including easy term loans, insurance facilities and tax benefits.

The youngest country in the world is India where more than 65 percent of the population is under 35 years of age while more than 50 percent of the population is under 25 years of age. It is also a big challenge for our country with great potential that how to train the youth with modern skills so that the youth is not able to run after the job and make others fit for the job. Today there is a lot of discussion about skill development and entrepreneurship and youths are being encouraged towards entrepreneurship with schemes like Skill Development and Start-up India, Today we are in the 21 st century where changes are seen in the appearance of the market every day. As we all know that our country is an agricultural country and $60 \%$ of our population is dependent on agriculture. Rural area is very important for the economy of our country, due to which development of rural entrepreneurship is very important Our rural areas are still very backward compared to other countries, due to which it is very important to talk about rural entrepreneurship.

Entrepreneurship can be found everywhere nowadays. Every profession has an entrepreneurial field. Agriculture certainly plays a very important role in that particular area. Entrepreneurship and agriculture are closely related. Agriculture is an industry that is worldwide and affects the entire population of the earth. And it is true that agricultural entrepreneurs will always be needed.

\section{Emerging Areas:}

\section{Food Processing}

Agro-based industrial products account for half of all exports to developing countries.

\section{Floriculture}

In many cases flowers can be cultivated on small tracts of land.

\section{Fisheries}


Many farmers practice fish farming to increase their income. However they do this on an amateur and small scale.

\section{Farm Technique}

Dependence on outdated and inefficient technologies leads to productivity and low income. While large-scale farmers have adopted modern technology on a large scale in India, most small farmers still mostly rely on old farming techniques through manual methods.

Types of Training undertaken by Agriculture Entrepreneur across Project Locations

\begin{tabular}{|c|c|c|c|c|c|c|}
\hline $\begin{array}{l}\text { Agri Entrepreneur } \\
\text { Category }\end{array}$ & A.P & Bihar & Jharkhand & $\begin{array}{l}\text { Madhya } \\
\text { Pradesh }\end{array}$ & Maharashtra & Odisha \\
\hline $\begin{array}{l}\text { Digital Financial } \\
\text { Services }\end{array}$ & 1 & 1 & 1 & & & \\
\hline Entrepreneurship & & & & & & 1 \\
\hline irrigation & 1 & & & & & \\
\hline Nursury & & & 1 & & 1 & \\
\hline polutry & & & & & 1 & \\
\hline soil testing & & & & 5 & & \\
\hline solid climber & & 1 & 5 & 6 & 11 & 6 \\
\hline agronomy & & 1 & 4 & & 9 & 4 \\
\hline Business Planning & & & & & 1 & \\
\hline Horticulture & & & & & & 1 \\
\hline $\begin{array}{l}\text { Marketing } \\
\text { Agronomy }\end{array}$ & & & & & 1 & \\
\hline Nursury & & & 1 & & & \\
\hline Pollutry & & & & & & 1 \\
\hline Soil Testing & & & & 6 & & \\
\hline Slow Climber & & 1 & 1 & 1 & 9 & 1 \\
\hline Agronomy & & & 1 & & 8 & 1 \\
\hline Goatery & & & & & 1 & \\
\hline Irrigation & & 1 & & & & \\
\hline \multicolumn{7}{|l|}{ Pollutry } \\
\hline Grand Total & 5 & 3 & 9 & 12 & 35 & 10 \\
\hline
\end{tabular}

Source: AGRICULTURE ENTREPRENEUR GROWTH AE Performance Study Global Alliance for Mass Entrepreneurship Syngenta Foundation India ( 2014 )

\section{Government Initiatives:}

The agriculture sector is given very high priority by the central government. To increase the income of farmers by directly and indirectly contributing and providing employment opportunities to the youth, start-ups are being encouraged. As a component under the National Agricultural 
Development Plan, the Innovation and Agricultural Entrepreneurship Development Program has been initiated to promote innovation and agricultural entrepreneurship by providing financial support and nurturing the incubation ecosystem. These start-ups are in various categories like agroprocessing, artificial intelligence, digital agriculture, agricultural mechanization, waste to wealth, dairy, fisheries etc.The Department of Agriculture, Cooperation and Farmers Welfare has selected 5 Knowledge Partners (KP) as the Center of Excellence.

24 Agribusiness Incubators (R-ABIs) have also been opened across the country.

The scheme has the following components:

Agripreneurship Orientation - with stipend of Rs 10,000 per month for a period of 2 months. Mentorship is provided on financial, technical, IP issues etc.

Seed Stage Funding of R-ABI Incubates - Funding up to Rs 25 lakh (85\% grant and 15\% contribution from Incubate).

Idea / Pre-Seed Stage Funding of Agripreneurs - Funding up to Rs 5 lakh (90\% conservative and $10 \%$ contribution from incubate).

Finalized the final list of start-ups to be financed through grant-in-aid, by instituting a rigorous process of applying for its programs and selection through various stages and based on two months of training goes. Training is provided on technical, finance, intellectual property, statutory compliance issues, etc. Providing mentorship to start-ups through milestone and deadline monitoring is part of the program. The central government gives high priority to the agricultural sector. Along with increasing their income by providing opportunities to farmers, the government is also focused on providing employment to maximum youth. In this context, start-ups related to agriculture are being promoted. Government is emphasizing on promoting start-ups and agroentrepreneurship to ensure the use of innovation and technology in agriculture and allied sectors. . Under this, the 'Innovation and Agro-Entrepreneurship Development' program has been adopted under the National Agricultural Development Scheme (RKVY). In the first phase in the financial year 2020-21, 112 start-ups in the fields of agro-processing, food technology and value addition will be provided in installments of Rs 1,185.90 lakh, which will contribute to increase the income of farmers. There is a need to promote start-ups and agri-entrepreneurs to ensure the use of innovation and technology in agriculture and allied sectors. The traditional knowledge of Indian communities should be combined with the skills and technology of young and agricultural graduates, so that the full potential of Indian agriculture in rural areas can be taken advantage of. Hackathons can be conducted to solve the identified problems and to meet the design needs for components and equipment, thereby reducing the hard work in farming. Though, agriculture in India has come a long way in agriculture in terms of food security, reaching out to the masses and being affordable. However, it is still marred by some challenges particularly low productivity that might happen because of various reasons; low value, hike in the input costs and leakages in the supply chain leading to a poor value chain. But a drop in the landholdings (average 1.4 hectares), 
dispersed land holdings, a shrinking agrarian land that is being consumed by the growing population, depleting groundwater levels and lack of mechanisation are some of the challenges for the growth of agriculture in India.

Unorganized marketing structure for produce, non-transparent agricultural markets, insufficientinfrastructure for transportation and storage, poor access to credit, and limited access to superior technology are some of the many maladies that affect the agrarian ecosystem.

Agri entrepreneurship is the need of the hour, particularly in India. Like varied formats of entrepreneurship, agri-entreprenuership also requires similar set of entrepreneurial skills, methods, and innovative mindset to create a robust agrarian ecosystem. While agri-entrepreneurshipcaters to a spectrum of ideas, the key areas mainly have been availability of information, management of farms and creating robust value chain.

In the past few years, some interesting disruptive start-ups have come to create a better agrarian ecosystem for the community. Some of them have been discussed below:

- 'EM3 Agri' that offers a unique concept of "pay per use farm services all the steps in agriproduction cycle. It includes including services starting from land development to postharvest services, helping the farmers gain edge over another farmers.

- 'Crofarm' is a major player that provides the farmers with a better financial deal for the farmers. It is a farm-to-business venture that uses a pattern of intelligentsupply chain solutions to reduce post-harvest costs and help the farmers getter better deal in terms of the price.

- 'Gold Farm' is a farm paraphernalia aggregator that collaborates with the local entrepreneurs who can create a pool farm equipment. These farm equipment in turn, are rented to the farmers at a nominal rate helping them reducing capital investment.

While this is not an exhaustive list of the agricultural based entrepreneurial ventures, they are definitely a comment on how entrepreneurship will help the farmers solve problems unique to their domain.

\section{References:}

[1] De Wolf, P., \& Schoorlemmer, H. (2007). Exploring the significance of entrepreneurship in agriculture. Resarch Institute of Organic Agriculture FiBL, CH-Frick.

[2] Ram, D., Singh, M. K., \& Prasad, A. (2012). Prospects of Agriculture and Allied Entrepreneurship Development in North-East India. Indian Research Journal of Extension Education, Special Issue, 2, 66-72.

[3] Dharwal, M., Parashar, D., Shuaibu, M. S., Abdullahi, S. G., Abubakar, S., \& Bala, B. B. (2020). Water pollution: Effects on health and environment of Dala LGA, Nigeria. Materials Today: Proceedings.

[4] Kumar, A. (2015). Entrepreneurship in agriculture development with special reference to Indian agricultural sector. Research front, 3(1), 85-94. 
International Journal of Modern Agriculture, Volume 9, No.3, 2020

ISSN: 2305-7246

[5] Vatsa, M., Chaudhary, S., \& Dharwal, M. (2020). Mechanics of environmental concern of car buyers in India. Materials Today: Proceedings.

[6] Dias, C. S., Rodrigues, R. G., \& Ferreira, J. J. (2019). Agricultural entrepreneurship: Going back to the basics. Journal of Rural Studies, 70, 125-138. 